\title{
Textile Industrial Effluent Treatment by Azo Dye Decolorizing Bacterial Consortium
}

\author{
Sunanda Kumari ${ }^{1}$ and Preeti Rajoriya ${ }^{2 *}$ \\ ${ }^{1}$ Department of Microbiology, Bhojia Institute of Life Sciences, \\ Baddi-173205, Himachal Pradesh, India \\ ${ }^{2}$ Department of Basic Science, Shri Siddhi Vinayak Institute of Management, Shri Siddhi \\ Vinayak Group of Institutions, Bareilly-211007, Uttar Pradesh, India
}

*Corresponding author

\section{A B S T R A C T}

\section{Keywords}

Textile effluent, Decolorization, Congo red dye, Bacterial consortium

Article Info

Accepted:

10 October 2019

Available Online:

10 November 2019
The textile industry is known to use massive amount of dyes to colour fabrics and subsequently the treatment of textile effluent is one of the greatest challenge. The aim of this research is to investigate the ability of the bacterial consortium to decolourise congo red dye. The synergy effects of microbial consortium offer considerable advantages over single culture in mineralisation of complex dye compounds. The consortia were developed by using isolated strain of Bacillus sp. named as AMS-XI and AMS-XIII from soil sample near the textile effluent. Environmental parameters such as $\mathrm{pH}$, salt, dye concentration, medium optimization (carbon and nitrogen sources), shaking condition were optimized by using yeast malt broth medium containing different concentration of Congo red dye (50 ppm and 100ppm). Maximum decolorizing efficiency was observed in a yeast malt broth medium containing $50 \mathrm{ppm}$ of congo red dye, sucrose, sodium nitrate, of bacterial consortium Bacillus sp. observed under 14 hours at temperature $37^{\circ} \mathrm{C} \mathrm{pH} 7.0$ and static conditions. Kinetics of $\%$ decolorization showed the $99.11 \%$ in 14 hours by bacterial consortium and biomass concentration of consortium $0.15 \mathrm{gm} / \mathrm{ml}$ was observed after 22 hours. TLC technique and proton NMR spectral analysis were also done and some esters, aliphatic and aromatic compounds were detected after decolorization. Industrial effluent treatment assay was done. It was observed that $76.68 \%$ COD removed after degradation in 10 hours. In future consortium can successfully be employed in the treatment of textile effluent.

\section{Introduction}

Wastewater generated by different production steps of a textile mill have high $\mathrm{pH}$, temperature, detergents, oil, suspended and dissolved solids, toxic and non-biodegradable matter, color and alkalinity. Due to their ease of manufacturing methodology, azo dye accounts for almost $80 \%$ of annual production of dyes all over the world. There are over 10,000 commercially available dyes with a production of over $7 \times 10^{5}$ tons per year (Tripathi et al., 2011). Waste water from fabric, printing and dyeing pose serious 
environmental problems because of their color and high chemical oxygen demand (COD) (Ayed et al., 2012). Dyes are widely used in printing, color, textile, rubber product, paper and pharmaceutical industries. Synthetic dyes have complex chemical structure so they are highly resistant to degradation. Textile industrial effluent contains about 280,000 tons of textile dyes which is discharged every year worldwide (Abo- State et al., 2017).

The dye effluents containing recalcitrant residue are discharged into rivers and lakes. The textile industry accounts for the largest consumption of dyestuffs, at nearly $80 \%$. Industrialization is vital to a nation's economy because it serves as a vehicle for development. However, there are associated problems resulting from the introduction of industrial waste products into the environment. Many of these products are problematic because of persistence (low biodegradability) and toxicity (Sriram and Reetha, 2015). Azo dyes are the largest class of synthetic dyes due to the ease and cost effectiveness of their synthesis and the highest range of colors (Perumal et al., 2012). Azo dyes are generally recalcitrant to biodegradation due to their complex structures and xenobiotic nature (Fetyan, 2013).

Congo red is a direct diazo dye with a structure benzidinediazo-bis-1-naphthylamine4-sulfonic acid sodium salt (formula: $\mathrm{C}_{32} \mathrm{H}_{22} \mathrm{~N}_{6} \mathrm{Na}_{2} \mathrm{O}_{6} \mathrm{~S}_{2}$; molecular weight: 696.66 $\mathrm{g} / \mathrm{mol}$ ). It is a secondary diazo dye. It is intended primarily for the coloration of paper products, used in medicine (as a biological stain) and as an indicator since it turns from red-brown in basic medium to blue in acidic, used to color textile and wood pulp. It is a recalcitrant and act as potent carcinogen and mutagenic because of the presence of aromatic amine group. Minute amounts of reactive group of azo dyes shows their visual effect with adverse impact in terms of total organic carbon (TOC) and chemical oxygen demand
(COD) and thus causing severe environmental problems worldwide. Azo dyes have long been recognized as a human urinary bladder carcinogen and tumorgenic in animals, cyanogenic in fishes, reduction in seed germination and induce dwarfism in plants (Perumal et al., 2012). In human some azo dyes have been linked to splenic sarcomas and chromosomal aberrations in mammalian cells (Sawhney et al., 2011).

There are several physicochemical and biological methods such as adsorption, flocculation- coagulation and precipitation, photolysis, chemical oxidation and reduction, electrochemical treatment for the removal of dyes from effluents (Viral and Patel, 2012). Presence of the dyes in aqueous ecosystem diminishes the photosynthesis by impeding the light penetration into deeper layers thereby deteriorating water quality and lowering the gas solubility. Furthermore the dyes and / or their degradation products may be toxic to flora and fauna (Talarposhti et al., 2001). Dyes may significantly affect photosynthetic activity in aquatic habit because of reduced light penetration and may also toxic to some aquatic life due to the presence of aromatics, metals, chlorides and toxic compounds (Saranraj et al., 2010).

Due to more excessive use of congo red in various industries posses a high threat to environment. Varieties of microorganisms including bacteria, fungi, yeasts, actinomycetes and algae are capable of degrading azo dyes, among which bacterial cells represent an inexpensive and promising tool for the removal of various azo dyes from textile dye effluents. In the current scenario, microbial or enzymatic treatment offers an indispensable, ecofriendly and cost-effective solution towards restoring azo dye polluted ecosystems. Bacteria capable of dye decolorization, either in pure cultures or in consortia, have been reported (Perumal et al., 
2012). Discharge of dye effluent from industries associates pollution problems. It has been documented that the safe method for azo dye biodegradation is combined aerobic treatment (Mabrouk et al., 2008; and Olukanni et al., 2009). Many organisms such as Bacillus, E. coli, Klebsiella, Enterobacter, Pseudomonas and a group of fungi, yeast have been studied for their decolonization of congo red dye (Chen et al., 2003; and Jaladoni-Buan et al., 2010). However, with increasing industrialization, the magnitude of the problem is constantly on rise and needs a plausible microbial solution. Thus, screening of microflora with effective decolorizing ability could evolve new indigenious strains to be used as bioremediation tools for removal of azo dyes.

It is found that in a microbial consortium the individual microbial strains may attack the dye molecule at different positions or may act on metabolites produced by the co-existing strains for further decomposition. In a study, Orange II has been shown to be completely decolorize by the consortium of two bacterial species, Enterobacter cloacae and Enterococcus casseliflavus whereas individual decolorization extent is $10 \%$ and $23 \%$, respectively in 15 minutes (Singh and Singh, 2017).

Several fungi with the capability to decolorize a wide range of dyes have been reported. For example, the white-rot fungi and brown-rot fungi are well-studied fungi groups with decolorization abilities. Other fungi, such as Aspergillus niger, Rhizopus arrhizus, and $R$. oryzae, can also decolorize and/or absorb diverse dyes and possess excellent color removal capabilities. The mechanism of fungal decolorization mainly involves two aspects, biodegradation and biosorption. The biodegradation capability of fungi is due to their extracellular, non-specific and nonselective enzyme system (Panpan Yang et al.,
2016). Virtually, dyes from all chemically distinct groups have been found prone to fungal oxidation due to their lignin modifying systems. Fungal degradation and decolorization of dyes through biosorption has been extensively reported or through mineralization (Bankole et al., 2018).

Nanotechnology enables the development of nanoscale particles of metals with novel and distinctive physico-chemical properties, and a broad range of scientific and technological applications. Nanoparticles have been used in a variety of electronic applications and commercial products, including imaging and medical apparatus, fabrics, cosmetics and water remediation technologies.

It was observed that silver ions may be reduced extracellularly using fungus Pleurotus sajor caju and the ability of Pleurotus sajor caju silver nanoparticles to decolorize congo red dye more as compared with its plain culture (Nithya and Ragunathan, 2011).

Bacterial enzymes, viz. azoreductase, laccase, and peroxidase, are able to degrade azo dye in promising percentages. As enzymes have a wide range of substrate specificity, easy immobilizable in nature and have high efficacy, it can be potentially used in textile effluent treatment. They are also substrate specific so they are able to catalyze only the desire reactions, and on the other hand, being biodegradable, it causes minimal environmental pollution.

Although certain types of dye do not get degraded efficiently, still, the use of enzymes is advantageous according to substrate specificity and may be efficiently used in textile water pre treatment.

The enzyme cleaves azo bond $(-\mathrm{N}=\mathrm{N}-)$ and transfers four electrons as reducing equivalent (Sarkar et al., 2017). Keeping the above 
consideration in mind following study was designed - Isolation of bacterial strains for model dye (congo red) decolorization, decolorization study by different bacterial consortium strains, identification of most suitable bacterial strains, screening for suitable medium, growth kinetics and \% decolorization by suitable bacterial consortium strains, NMR spectral analysis studies, industrial effluent treatment assay.

\section{Materials and Methods}

\section{Isolation of bacterial strains for model dye (congo red) decolorization}

Congo red dye decolorizing bacterial strains were isolated from the soil samples taken from effluent discharge point outside the Birla Textile Company, Baddi (H.P.). Isolation was done by using serial dilution technique and streak method (Aneja $4^{\text {th }}$ revised edition).

\section{Decolorization study by spectrophotometric method}

$800 \mathrm{ml}$ yeast malt broth (YMB) was prepared and supplemented with $50 \mathrm{ppm}$ model dye (congo red). Transferred $50 \mathrm{ml}$ prepared medium in 16 flasks. Different pure bacterial strains were inoculated in 14 flasks having 50 $\mathrm{ml}$ prepared broth except positive and negative control. Then all flasks were incubated these flasks at $37^{\circ} \mathrm{C}$ for 24 hours. After 24 hours incubation, optical density (O.D.) was recorded at $495.2 \mathrm{~nm}$ by using UV-VIS spectrophotometer to calculate percentage decolorization (Sawhney and Kumar, 2011) as follows.

$\%$ decolorization

$=\frac{\mathrm{C}-\mathrm{T}}{\mathrm{C}} \times 100$

Where, $\mathrm{C}=$ absorbance of control flask and $\mathrm{T}$ $=$ absorbance of test flasks.
Identification of most suitable bacterial strains

Most suitable bacterial consortium strains were identified based on the combination of different bacterial strains decolorizing model dye by observing their \% decolorization. The most suitable bacterial consortium strains which showed fast decolorization, their identification was done by using microscopy and biochemical testing.

\section{Microscopic tests}

Microscopic tests such as gram staining, acid fast staining, endospore staining, capsule staining and motility of 24 hours old both the cultures AMS-XI and AMS-XIII were done and then observed under microscope at 100X.

\section{Biochemical tests}

Biochemical testing of both the cultures were done such as starch hydrolysis test, gelatin hydrolysis test, casein hydrolysis test, urease test, sugar fermentation test, indole production test, methyl -red test, Voges Proskauer test, citrate utilization test, catalase test, nitrate reductase test.

\section{Effect of $\mathrm{pH}$ and sodium chloride $(\mathrm{NaCl})$ on growth of both strains}

\section{Effect of pH}

In four test tubes, each containing $5 \mathrm{ml}$ YMB broth were prepared at different $\mathrm{pH}$ (4.5 and 6.5) and inoculated two test tubes of $\mathrm{pH} 4.5$ separately with monocultures AMS-XI and AMS-XIII.

Other two test tubes of $\mathrm{pH} 6.5$ were also inoculated separately with monocultures AMS-XI and AMS-XIII and incubated them at $37^{\circ} \mathrm{C}$ for 24 hours. After incubation period, $4 \mathrm{ml}$ of each test tube was centrifuged at 
$10,000 \mathrm{rpm}$ for 10 minutes and supernatant was removed, growth was checked by taking O.D. at $600 \mathrm{~nm}$ by dissolving the pellet in distilled water.

\section{Effect of $\mathrm{NaCl}$}

10 test tubes each containing $5 \mathrm{ml}$ normal saline were prepared with $\mathrm{NaCl}$ concentrations $(2 \%, 3 \%, 4 \%, 5 \%, 6 \%)$. At each concentration a pair of test tubes was prepared and inoculated one test tube from each pair with AMS-XI and others with AMS-XIII. All of them were incubated at $37^{0} \mathrm{C}$ for 24 hours.

After incubation period, $4 \mathrm{ml}$ of each test tube was centrifuged at $10,000 \mathrm{rpm}$ for 10 minutes and supernatant was removed, growth was checked by taking O.D. at $600 \mathrm{~nm}$ by dissolving the pellet in distilled water.

\section{Tests on different dyes and mixture of dyes}

\section{Test on different dyes}

Four flasks each having $50 \mathrm{ml}$ YMB broth supplemented with 50ppm of four different dyes (congo red, amido black, acid orange $\mathrm{G}$, rhodamine B) and marked them according to their names. Positive controls of each dye were also prepared. Except positive controls, all the flasks were inoculated with $1 \mathrm{ml}$ of 24 hours old bacterial consortium culture and incubated for 24 hours at $37^{\circ} \mathrm{C}$. After incubation period the $\%$ decolorization of each dye was checked by recording O.D. at 495.6 $\mathrm{nm}$ in UV-VIS spectrophotometer.

\section{Test on mixture of dyes}

$50 \mathrm{ml}$ YMB broth containing flask supplemented with $25 \mathrm{ppm}$ of each dye (congo red, amido Black, Acid orange G) was prepared. Flask was incubated with $1 \mathrm{ml}$ of 24 hours old bacterial consortium culture and incubated at $37^{\circ} \mathrm{C}$ for 24 hours.
Test for decolorization on various concentrations of congo red dye

6 flasks of YMB broth medium with different concentration of congo red dye (50 ppm, 100 ppm, 150 ppm, 200 ppm, 250 ppm, 300 ppm) were prepared with their respective positive controls having respective ppm of congo red dye. All the flasks except positive controls were inoculated with $500 \mu \mathrm{l}$ of 24 hours old bacterial consortium incubated them at $37^{\circ} \mathrm{C}$ and observed them within 10 hours. Their decolorization was observed by recording O.D. at $495.6 \mathrm{~nm}$ with respect to their respective positive controls.

\section{Medium optimization}

Medium optimization was done to obtain fast decolorization in lesser time by optimizing different carbon and nitrogen sources with their different concentrations.

\section{Optimization of carbon source}

Medium with basic components [malt $\operatorname{extract}(3 \mathrm{gm} / \mathrm{L}), \quad$ yeast $\quad \operatorname{extract}(5 \mathrm{gm} / \mathrm{L})$, peptone $(5 \mathrm{gm} / \mathrm{L})]$, different carbon sources(dextrose, sucrose, lactose, fructose, maltose, starch) with their different concentrations $(0.5 \%, 1.0 \%, 1.5 \%, 2 \%)$ at $\mathrm{pH}$ 7.0 and $50 \mathrm{ppm}$ congo red dye was prepared and inoculated them $500 \mu$ l of 24 hours old bacterial consortium. Flasks were incubated at $37^{\circ} \mathrm{C}$ and observed their \% decolorization within 14 hours to obtain which carbon source shows fast decolorization in minimum time by taking O.D. at $495.6 \mathrm{~nm}$ with respect to their positive and negative control.

\section{Optimization of nitrogen source}

The optimized carbon source containing medium, various nitrogen source (ammonium sulphate, ammonium chloride, ammonium nitrate, sodium nitrate) each with their 
different concentrations $(0.25 \%, 0.5 \%, 0.75 \%$, $1 \%$ ) at $\mathrm{pH} 7.0,50 \mathrm{ppm}$ congo red dye were prepared in flasks and inoculated them with $500 \mu 1$ of 24 hours old bacterial consortium. Flasks were incubated at $37^{\circ} \mathrm{C}$ for 14 hours. The O.D. was observed at $495.6 \mathrm{~nm}$ with respect to their positive and negative control.

Test for effect of rotation per minute (rpm) on decolorization

10 flasks containing $50 \mathrm{ml}$ optimized medium with $50 \mathrm{ppm}$ congo red dye and inoculated with $500 \mu$ of 24 hours old bacterial consortium strains. Incubated 9 flasks at different rpm (80 rpm, $90 \mathrm{rpm}, 100 \mathrm{rpm}, 110$ rpm, $120 \mathrm{rpm}, 130 \mathrm{rpm}, 140 \mathrm{rpm}, 150 \mathrm{rpm}$, $160 \mathrm{rpm}$ ) respectively and 1 flask at static condition. After 10 hours O.D. was recorded at $495.6 \mathrm{~nm}$ for $\%$ decolorization with reference to their positive and negative control.

\section{$\%$ inoculums optimization}

$1200 \mathrm{ml}$ optimized medium was prepared and inoculated with 24 hours old 2 times loopful culture of bacterial consortium. Incubated the inoculated medium at $37^{\circ} \mathrm{C}$ for 24 hours.

After incubation, medium was centrifuged in sterile centrifuge tube at $10,000 \mathrm{rpm}$ at $4{ }^{\circ} \mathrm{C}$ to obtain the pellet. Wet weight and dry weight of obtained biomass was taken.

Wet wt. of biomass (gm)

= wt. of centrifuge tube having pellet $(\mathrm{gm})-$ wt. of blank centrifuge tube (gm).

\section{Dry weight of biomass}

Dry weight was taken by mixing the pellet with $5 \mathrm{ml}$ sterile media to make a thick suspension. A filter paper was dried in oven at $100^{\circ} \mathrm{C}$ for 10 minutes and weighed. $200 \mu \mathrm{l}$ of suspension was spreaded on the filter paper and dried in oven at $100^{\circ} \mathrm{C}$ for 10 minutes and weighted.

Dry wt. of biomass (gm)

$=$ wt. of filter paper dried with $200 \mu \mathrm{l}$ suspension $(\mathrm{gm})$ - wt. of dried blank filter paper $(\mathrm{gm})$.

Five flasks containing $10 \mathrm{ml}$ optimized medium with 50 ppm congo red dye were inoculated with obtained suspension of culture with concentrations $(0.2 \%, 0.4 \%, 0.6 \%, 0.8 \%$, $1 \%)$ means $140 \mu \mathrm{l}, 280 \mu \mathrm{l}, 420 \mu \mathrm{l}, 560 \mu \mathrm{l}, 700$ $\mu 1$ were inoculated respectively and incubated at $37^{\circ} \mathrm{C}$ for 10 hours. Then $4 \mathrm{ml}$ from each flask was centrifuged at $10,000 \mathrm{rpm}$ for 10 minutes in separate vials, their supernatant was collected and the $\%$ decolorization was observed by taking O.D. at $495.6 \mathrm{~nm}$ with respect to their positive and negative control.

\section{Growth kinetics and \% decolorization study by bacterial consortium strains}

Five flasks, each with $64 \mathrm{ml}$ optimized medium supplemented with $50 \mathrm{ppm}$ congo red dye except negative control were prepared and marked them as positive control, negative control, AMS-XI, AMS-XIII and consortium. 24 hours old cultures of AMS-XI, AMS-XIII and consortium were inoculated in their respective marked flasks and incubated at $37^{\circ} \mathrm{C}$ for 1 hour. O.D. was monitored after every 1 hour at $495.6 \mathrm{~nm}$ for \% decolorization and at $600 \mathrm{~nm}$ for biomass.

\section{NMR spectral analysis studies}

NMR spectral analysis was done to analyze the metabolites produced after decolorization. For sample preparation NMR spectral analysis, Thin Layer Chromatography (TLC) technique was also employed.

Two flasks each having $100 \mathrm{ml}$ optimized medium were inoculated with bacterial 
consortium and incubated for 24 hours at $37^{\circ} \mathrm{C}$. After incubation period, transfer them separately in two clean $250 \mathrm{ml}$ separating funnel and add $75 \mathrm{ml}$ of ethyl acetate was added in each funnel. For proper mixing of ethyl acetate by continuous shaking, the medium incubated overnight. Thick emulsion layer and a thin transparent layer was observed above the medium in both funnels after overnight period. The emulsion layer with transparent layer was separated from medium in both funnels and centrifuged to take the transparent layer in two test tubes. Transparent layer obtained contain metabolites after decolorization of congo red dye dissolved in ethyl acetate. Concentrate both flasks at low temperature on heating mantle until it remain $1.5 \mathrm{ml}$ in each flask. That obtained $1.5 \mathrm{ml}$ concentrated samples were transferred in two $2 \mathrm{ml}$ vial separately and marked them. After that, Thin Layer Chromatography (TLC) was done to check the presence of metabolites from vial I and separation of pure metabolite from II $^{\text {nd }}$ vial.

\section{Thin Layer Chromatography}

Two silica gel containing TLC plates one medium sized and other large sized plates were prepared. $100 \mu \mathrm{l}$ of sample from vial I on center of one end of medium sized TLC plate and on large sized TLC plate $100 \mu$ of sample from vial $\mathrm{II}^{\text {nd }}$ at six points with small distances on one end of plate was loaded. These two plates were kept in TLC chamber containing solvent system hexane: ethyl acetate: methanol $(5: 3: 1) \mathrm{v} / \mathrm{v}$. TLC Chamber was kept for 3-4 hours with tight covering to prevent the contact of air with the solvent system.

After 3-4 hours the plates were observed for metabolites presence in the form of colored small circles under UV- transilluminator. From large sized TLC plate small circle form each loaded sample having same resolution factor were observed and scratched them carefully from TLC plate. Scratched silica gel was taken in a $2 \mathrm{ml}$ vial and mixed it with 1 $\mathrm{ml}$ of ethyl acetate and centrifuged it at 10,000 rpm for 10 minutes. Supernatant contain transparent layer was taken carefully in other clean $2 \mathrm{ml}$ vial and marked it as S AMS-XIII. Vial I (marked as AMS-XIII) having $1.5 \mathrm{ml}$ sample and S AMS-XIII marked vial both were completely dried in their respective vial.

Resolution factor

$=\underline{\text { Distance travelled by solute }}$

Distance travelled by solvent

\section{NMR spectral analysis}

For Proton Nuclear Magnetic Resonance (NMR) dried sample in both vials was dissolved in DMSO-d6 and transferred in 5 $\mathrm{mm}$ - diameter tubes and analyzed at $900 \mathrm{~Hz}$.

\section{Industrial effluent treatment assay}

Industrial effluent treatment assay was done by checking the Chemical Oxygen Demand (COD) of waste water.50ml water sample were taken in I conical flask and $50 \mathrm{ml}$ tap water blank standard in II conical flask. $5 \mathrm{ml}$ of $\mathrm{K}_{2} \mathrm{Cr}_{2} \mathrm{O}_{7}$ solution was added in each flask and kept both flasks in water bath at $100^{\circ} \mathrm{C}$ for 1 hour. Allowed the flasks to cool for $10 \mathrm{~min}$. and $5 \mathrm{ml}$ of potassium iodide was added in each flask. $10 \mathrm{ml}$ of sulfuric acid was added in flasks and titrated the contents in each flask with $0.1 \mathrm{M}$ sodium thiosulphate until the appearance of pale yellow colour. $1 \mathrm{ml}$ of starch solution was added in each flask for appearance of blue colour and then, titrated again with $0.1 \mathrm{M}$ sodium thio sulphate until the blue colour disappeared. Check the initial and final reading during titration for both flasks and check COD level

Initial COD $(\mathrm{mg} / \mathrm{L})$

$=\underline{8 \times \mathrm{C} \times(\mathrm{B}-\mathrm{A})}$----- $^{(1)}$

\section{$\mathrm{S}$}


Where, $\mathrm{C}=$ concentration of titrant $(\mathrm{m} \mathrm{Mol} / \mathrm{L})$, $\mathrm{A}=$ Volume of titrant used for blank $(\mathrm{ml}), \mathrm{B}=$ Volume of titrant used for sample $(\mathrm{ml}), \mathrm{S}=$ volume of water sample taken $(\mathrm{ml})$

Inoculated the $50 \mathrm{ml}$ water sample containing conical flask and incubated it at $37^{\circ} \mathrm{C}$ for 10 hours. Repeated the steps for COD same as used to check the initial COD of wastewater sample without inoculation.

Final COD $(\mathrm{t})$

$=\frac{8 \times \mathrm{C} \times(\mathrm{B}-\mathrm{A}) \times 10}{\mathrm{~S}}----(2)$

From (1) and (2)

COD removal $(\%)$

$=\underline{\text { Initial COD- Final COD }(\mathrm{t})} \times 100$

Initial COD

\section{Results and Discussions}

The results obtained are displayed in the form of tables 1-13 and figures (Fig. 1-13).

Isolation of bacterial strains for model dye (congo red) decolorization

After spread plate method, 14 different strains were obtained. Then these strains were isolated by streak plate method on YMB agar medium and marked as AMS-I, AMS-II, AMS-III, AMS-IV, AMS-V, AMS-VI, AMSVII, AMS-VIII, AMS-IX, AMS-X, AMS-XI, AMA-XII, AMS-XIII and AMS-XIV respectively. Congo red dye showed the peak at $495.6 \mathrm{~nm}$.

Decolorization study by spectrophotometric method

From table 1 it was observed that AMS-XIII showed maximum decolorization with 96.81\%. In compared to this study, Jadhav et al., (2011) has also reported that Bacillus sp. and Pseudomonas sp. produced level (89\%) of decolorization of Orange 39 at 144 hours. Perumal et al., (2012) has reported five bacterial strains two Proteus. Klebsiella sp., Salmonella sp., Pseudomonas sp., and bacterial consortium with 67\%, 81\%, 90\%, $77 \%, \quad 65 \%$ and $98 \%$ decolorization respectively at static conditions within 48 hours under $\mathrm{pH} 7.0$ at $37^{\circ} \mathrm{C}$.

\section{Identification of most suitable bacterial consortium strains}

From table 2 it was observed that combination of AMS-XIII with other isolated strains showed decolorization above $90 \%$. But the highest decolorization bacterial consortium observed was AMS-XIII and AMS-XI. Presence of AMS-XI, AMS-XIII showed fast and highest \% decolorization. In contrast, Joshi et al., (2015) isolated the bacterial consortium from textile effluent which degrade the Methyl Red and Carbol Fuchsin.

\section{Microscopy and biochemical tests}

Effect of $\mathrm{NaCl}$ and $\mathrm{pH}$ on the growth of both strains

AMS-XIII and AMS-XI cultures showed growth well in low $\mathrm{NaCl}$ concentration below $2 \%$ and at $\mathrm{pH}$ near neutral that is 6.5 and 7.0 (Table 4 and 5). Abo-State et al., 2017 have also reported the maximum decolorization $(90.03 \%)$ of congo red dye by $B$. cereus at $\mathrm{pH}$ 7.0 .

\section{Test on different dyes and mixture of dyes}

Bacterial consortium also decolorized amido black, congo red, acid orange $G$ and rhodamine $\mathrm{B}$ and mixture of dyes (acid orange, congo red, amido black, each with 25ppm) in YMB broth within 24 hours incubation (Table 6). In contrast, Diazong Cui et al., 2014 have also investigated that 
Klebsiella sp. decolorized the different dyes Methyl Red, Congo Red, Orange I and Methyl Orange by almost $100 \%$ (100 mg/L) in 48 hours at $\mathrm{pH} 4$ to 9 .

Test for decolorizatin on different concentrations of congo red dye

Bacterial consortium strains showed 99\% decolorization of 50ppm and $100 \mathrm{ppm}$ after 14 hours incubation period at $37^{\circ} \mathrm{C}$.

\section{Medium optimization}

Medium optimization for carbon and nitrogen source is given below:

\section{Optimization of Carbon Source and nitrogen source}

Bacterial consortium showed highest decolorization in carbon source sucrose at concentration $1.5 \%$ and nitrogen source sodium nitrate at concentration $0.5 \%$.

After optimization medium in which bacterial consortium showed fast decolorization in 14 hours contained components.

\section{Test for effect of RPM on \% decolorization}

The inoculated flasks showed the decrease in decolorization efficiency during shaking conditions. Nedra Asses et al., 2018 reported the increase in congo red dye decolorization by Aspergillus niger with increase in rpm from 0 to 150 .

\section{$\%$ inoculums optimization}

The increase in $\%$ decolorisation with the increase in $\%$ inoculums (consortium) was observed after 10 hours. Almost similar results were also reported by Abd El- Kader et al., 2018 who isolated the microbial consortium from sheep farm compost which was effective in the decolorization of about $98 \%$ Congo red dye from wastewater after $24 \mathrm{~h}$ of incubation. An inoculum concentration $2.5 \%$ was capable of removing more than $75 \%$ of the dye from wastewater.

Wet wt. of biomass (gm)

$=28.325-26.358=1.967 \mathrm{gm}$

Dry wt. of biomass

$=0.476-0.445=0.03 \mathrm{gm}$

Growth kinetics and \% decolorization study by bacterial consortium strains

The growth curves of AMS-XIII, AMS-XI and consortium it was observed that AMSXIII was a slow growing culture which shows fast growth with its consortium AMS-XI in 10 hours (Table 10). It was observed that AMSXIII decolorized dye and its cosortium with AMS-XI showed fast decolorization in 10 hours (Table 11 \& Fig. 8).

\section{NMR spectral analysis}

\section{Thin Layer Chromatography (TLC)}

The TLC analysis revealed the presence of separated metabolites on both marked plates under the UV- transilluminator. From plate (a) metabolites with same resolution factor were separated. Similarly, Gounder vimala et al., (2015) have also reported the presence of degraded products of azo dye decolorization by Micrococcus sp. on TLC plate. Mohamed El Bouraie et al., 2016 also reported two bands of decolorized dye RB5 dye which was cleaved into two fragments observed on the TLC chromatograms under UV light.

\section{NMR spectral analysis}

Similar results were findings of NMR analysis reported by Khehra et al., 2004 who studied the TLC and NMR analysis of the dye C.I. 
Table.1

\begin{tabular}{|c|c|c|c|c|}
\hline \multicolumn{5}{|c|}{ Rf value } \\
\hline Spot I & Spot II & Spot III & Spot IV & Spot V \\
\hline $\mathbf{0 . 4 9}$ & 0.47 & 0.47 & 0.48 & 0.50 \\
\hline
\end{tabular}

Table.2 Represention of the $\%$ decolorization of $50 \mathrm{ppm}$ congo red dye by different isolated strains from soil

\begin{tabular}{|l|c|c|}
\hline S.No. & Isolated strains & $\begin{array}{c}\text { \% decolorization } \\
(\%)\end{array}$ \\
\hline $\mathbf{1 .}$ & AMS-I & 2.00 \\
\hline $\mathbf{2 .}$ & AMS-II & 27.06 \\
\hline $\mathbf{3 .}$ & AMS-III & 75.30 \\
\hline $\mathbf{4 .}$ & AMS-IV & 65.20 \\
\hline $\mathbf{5 .}$ & AMS-V & 74.74 \\
\hline $\mathbf{6 .}$ & AMS-VI & 47.43 \\
\hline $\mathbf{7 .}$ & AMS-VII & 1.00 \\
\hline $\mathbf{8 .}$ & AMS-VIII & 0.00 \\
\hline $\mathbf{9 .}$ & AMS-IX & 25.13 \\
\hline $\mathbf{1 0 .}$ & AMS-X & 1.00 \\
\hline $\mathbf{1 1 .}$ & AMS-XI & 0.00 \\
\hline $\mathbf{1 2 .}$ & AMS-XII & 79.70 \\
\hline $\mathbf{1 3}$ & AMS-XIII & 96.81 \\
\hline $\mathbf{1 4}$ & AMS-XIV & 0.00 \\
\hline
\end{tabular}

Table.3 Represention of the \% decolorization of different consortium strains

\begin{tabular}{|c|c|c|}
\hline S.No. & Consortium & \% decolorization $(\boldsymbol{\%})$ \\
\hline $\mathbf{1 .}$ & AMS-III and AMS-XIV & 93.10 \\
\hline $\mathbf{2 .}$ & AMS-XIII and AMS-XII & 95.23 \\
\hline $\mathbf{3 .}$ & AMS-XIII and AMS-XI & 98.35 \\
\hline $\mathbf{4 .}$ & AMS-XIII and AMS-X & 91.60 \\
\hline $\mathbf{5 .}$ & AMS-XIII and AMS-IX & 95.67 \\
\hline $\mathbf{6 .}$ & AMS-XIII and AMS-VIII & 90.23 \\
\hline $\mathbf{7 .}$ & AMS-XIII and AMS-VII & 96.23 \\
\hline $\mathbf{8 .}$ & AMS-XIII and ANS-VI & 95.67 \\
\hline $\mathbf{9 .}$ & AMS-XIII and AMS-V & 92.01 \\
\hline $\mathbf{1 0 .}$ & AMS-XIII and AMS-IV & 96.47 \\
\hline $\mathbf{1 1 .}$ & AMS-XIII and AMS-III & 90.43 \\
\hline $\mathbf{1 2 .}$ & AMS-XIII and AMS-II & 92.56 \\
\hline $\mathbf{1 3 .}$ & AMS-XIII and AMS-I & 90.24 \\
\hline
\end{tabular}


Table.4 Representing microscopic and biochemical testing of isolated consortium of monocultures AMS-XIII and AMS-XI for their identification

\begin{tabular}{|c|c|c|c|}
\hline S.No. & Biochemical tests & AMS-XIII & AMS-XI \\
\hline 1. & Gram staining & Gram +ve & Gram +ve \\
\hline 2. & Shape & Rod & Rod \\
\hline 3. & Acid fast staining & Non acid fast & Non acid fast \\
\hline 4. & Endospore staining & Non endospore & Non endospore \\
\hline 5. & Capsule staining & Non capsulated & Non capsulated \\
\hline 6. & Motility & Non motile & Motile \\
\hline 7. & Starch hydrolysis & $+v e$ & -ve \\
\hline 8. & Gelatin hydrolysis & +ve & -ve \\
\hline 9. & Casein hydrolysis & +ve & -ve \\
\hline 10. & Urease & +ve & -ve \\
\hline 11. & Sucrose & $+\mathrm{ve}$ & -ve \\
\hline 12. & Glucose & +ve & -ve \\
\hline 13. & Fructose & +ve & -ve \\
\hline 14. & Lactose & $+v e$ & -ve \\
\hline 15. & Mannitol & +ve & -ve \\
\hline 16. & Mannose & $+\mathrm{ve}$ & -ve \\
\hline 17. & Ionositol & +ve & -ve \\
\hline 18. & Xylose & + ve & -ve \\
\hline 19. & Catalase & +ve & -ve \\
\hline 20. & Methyl red & +ve & -ve \\
\hline 21. & V-P & $+v e$ & -ve \\
\hline 22. & Indole & +ve & -ve \\
\hline 23. & Nitrate reductase & +ve & -ve \\
\hline
\end{tabular}

*Note- +ve = Positive; - ve= Negative

Table.5 Represention of the growth of AMS-XIII and AMS-XI at various $\mathrm{NaCl}$ concentrations

\begin{tabular}{|l|c|c|c|}
\hline \multirow{2}{*}{ S.No. } & NaCl concentrations & \multicolumn{2}{|c|}{ O.D. at 600 nm } \\
\cline { 3 - 4 } & $(\boldsymbol{\%})$ & AMS-XIII & AMS-XI \\
\hline & Control & 0.188 & 0.833 \\
\hline 1. & 2 & 0.126 & 0.219 \\
\hline 2. & 3 & 0.127 & 0.136 \\
\hline 3. & 4 & -0.007 & 0.215 \\
\hline 4. & 5 & -0.033 & 0.174 \\
\hline 5. & 6 & -0.020 & -0.028 \\
\hline 6. & 7 & -0.017 & -0.028 \\
\hline
\end{tabular}


Table.6 Representation of the growth of AMS-XIII and AMS-XI at different $\mathrm{pH}$

\begin{tabular}{|l|c|c|c|}
\hline \multirow{2}{*}{ S.No. } & \multirow{2}{*}{$\mathbf{p H}$} & \multicolumn{2}{|c|}{ O.D. at 600nm } \\
\cline { 3 - 4 } & & AMS-XIII & AMS-XI \\
\hline 1. & 4.5 & 0.012 & 0.028 \\
\hline 2. & 6.5 & 0.128 & 0.762 \\
\hline
\end{tabular}

Table.7 Representation of the \% decolorization of different dyes with 50ppm concentration by bacterial consortium

\begin{tabular}{|c|c|c|c|c|}
\hline S.No. & Different dyes & $\begin{array}{c}\text { Positive control O.D. } \\
\mathbf{( 4 9 5 . 6 n m )}\end{array}$ & $\begin{array}{c}\text { O.D. at } \\
\mathbf{4 9 5 . 6 n m}\end{array}$ & $\begin{array}{c}\text { \% decolorization by } \\
\text { consortium }(\mathbf{\%})\end{array}$ \\
\hline $\mathbf{1 .}$ & Amido Black & 0.549 & 0.270 & 78.32 \\
\hline $\mathbf{2 .}$ & Congo red & 0.91 & 0.015 & 98.35 \\
\hline $\mathbf{3 .}$ & Acid Orange G & 2.278 & 0.007 & 99.69 \\
\hline $\mathbf{4 .}$ & Rhodamine B & 2.598 & 2.424 & 6.69 \\
\hline $\mathbf{5 .}$ & $\begin{array}{c}\text { Mixture of dyes (amido } \\
\text { black, congo red, acid } \\
\text { orange G) }\end{array}$ & 2.548 & 0.010 & 99.60 \\
\hline
\end{tabular}

Fig.1 Chemical structure of Congo red

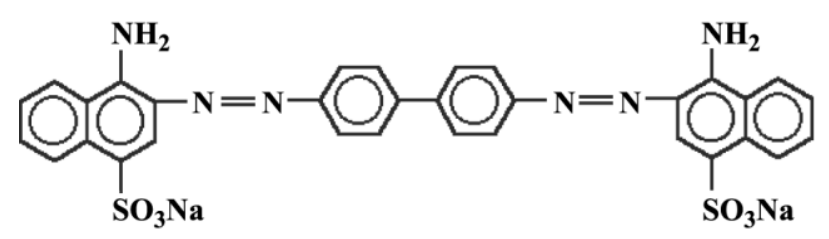

Fig.2 Representation of YMB media with 50ppm congo red dye (a) before decolorization, (b) after decolorization of 24 hours incubation period by suitable bacterial consortium strains at $37^{\circ} \mathrm{C}$

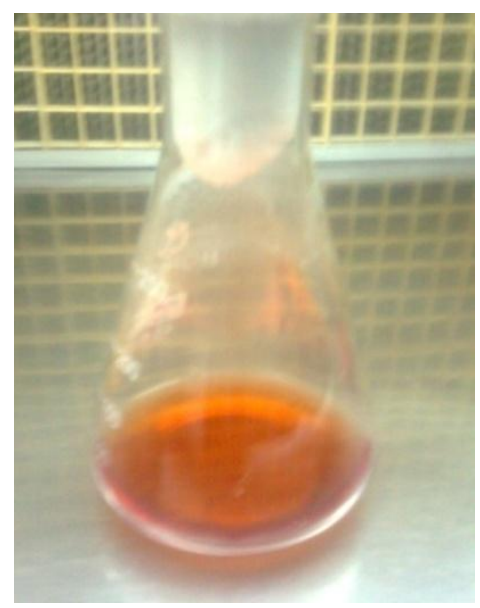

(a)

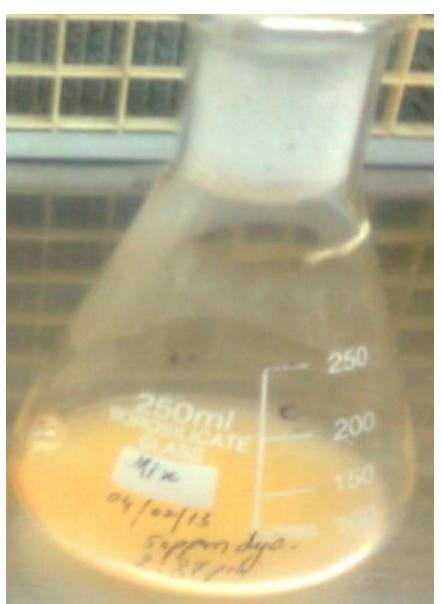

(b) 
Table.8 Optimization of various carbon sources at various concentrations for $\%$ decolorization of 50ppm congo red dye in 14 hours by bacterial consortium

\begin{tabular}{|c|c|c|c|c|c|}
\hline S. No. & Carbon sources & Concentrations (\%) & $\begin{array}{l}\text { O.D.at } \\
\text { 495.6nm }\end{array}$ & $\begin{array}{c}\% \\
\text { decolorization }\end{array}$ & $\begin{array}{l}\text { pH after } \\
16 \text { hours }\end{array}$ \\
\hline & Positive control & & 0.891 & - & - \\
\hline \multirow[t]{4}{*}{1.} & Dextrose & 0.5 & 0.215 & 75.86 & 5.95 \\
\hline & & 1 & 0.360 & 59.59 & 5.86 \\
\hline & & 1.5 & 0.544 & 38.94 & 5.89 \\
\hline & & 2 & 0.600 & 32.65 & 5.88 \\
\hline \multirow[t]{4}{*}{2.} & Sucrose & 0.5 & 0.176 & 80.24 & 5.98 \\
\hline & & 1 & 0.116 & 86.98 & 6.00 \\
\hline & & 1.5 & 0.096 & 89.22 & 5.92 \\
\hline & & 2 & 0.405 & 54.54 & 5.96 \\
\hline \multirow[t]{4}{*}{3.} & Lactose & 0.5 & 0.519 & 41.75 & 5.98 \\
\hline & & 1 & 0.729 & 18.18 & 5.97 \\
\hline & & 1.5 & 0.800 & 10.21 & 5.99 \\
\hline & & 2 & 0.667 & 25.14 & 5.99 \\
\hline \multirow[t]{4}{*}{4.} & Fructose & 0.5 & 0.783 & 12.12 & 6.12 \\
\hline & & 1 & 0.804 & 09.7 & 6.07 \\
\hline & & 1.5 & 1.008 & $-\mathrm{ve}$ & 6.22 \\
\hline & & 2 & 0.876 & 1 & 6.45 \\
\hline \multirow[t]{4}{*}{5.} & Starch & 0.5 & 0.420 & 52.8 & 5.92 \\
\hline & & 1 & 0.544 & 38.94 & 5.99 \\
\hline & & 1.5 & 0.657 & 26.26 & 5.97 \\
\hline & & 2 & 0.598 & 32.88 & 5.95 \\
\hline \multirow[t]{4}{*}{6.} & Maltose & 0.5 & 0.654 & 26.95 & 5.95 \\
\hline & & 1 & 1.182 & $-\mathrm{ve}$ & 5.98 \\
\hline & & 1.5 & 0.866 & 2 & 5.92 \\
\hline & & 2 & 0.650 & 27 & 5.96 \\
\hline
\end{tabular}


Table.9 Representation of optimization of various nitrogen sources at various concentrations for $\%$ decolorization in 14 hours by bacterial consortium

\begin{tabular}{|c|c|c|c|c|c|}
\hline \multirow[t]{2}{*}{ S. No. } & Nitrogen sources & $\begin{array}{c}\text { Concentrations } \\
(\%)\end{array}$ & $\begin{array}{c}\text { O.D.at } \\
\text { 495.6nm }\end{array}$ & $\begin{array}{c}\% \\
\text { Decolorization } \\
(\%)\end{array}$ & $\begin{array}{c}\text { pH after } 16 \\
\text { hours }\end{array}$ \\
\hline & Positive control & - & 1.351 & - & - \\
\hline \multirow[t]{4}{*}{1.} & \multirow[t]{4}{*}{ Ammonium chloride } & 0.25 & 0.122 & 90.96 & 5.78 \\
\hline & & 0.5 & 0.140 & 89.63 & 5.73 \\
\hline & & 0.75 & 0.953 & 29.45 & 5.61 \\
\hline & & 1 & 1.092 & 19.17 & 5.99 \\
\hline \multirow[t]{4}{*}{2.} & \multirow[t]{4}{*}{ Ammonium nitrate } & 0.25 & 0.295 & 78.16 & 6.46 \\
\hline & & 0.5 & 0.206 & 84.75 & 6.34 \\
\hline & & 0.75 & 0.276 & 79.57 & 6.18 \\
\hline & & 1 & 1.183 & 12.43 & 5.88 \\
\hline \multirow[t]{4}{*}{3.} & \multirow[t]{4}{*}{ Ammonium sulphate } & 0.25 & 0.175 & 87.04 & 5.88 \\
\hline & & 0.5 & 0.120 & 91.11 & 5.90 \\
\hline & & 0.75 & 0.511 & 62.17 & 5.80 \\
\hline & & 1 & 1.211 & 10.36 & 5.91 \\
\hline \multirow[t]{4}{*}{4.} & \multirow[t]{4}{*}{ Sodium nitrate } & 0.25 & 0.080 & 94.07 & 6.34 \\
\hline & & 0.5 & 0.046 & 96.59 & 6.28 \\
\hline & & 0.75 & 0.116 & 91.41 & 6.60 \\
\hline & & 1 & 0.076 & 94.37 & 6.29 \\
\hline
\end{tabular}

Table.10 Representation of standardized medium

\begin{tabular}{|c|c|}
\hline Components & Quantity \\
\hline Malt extract & $3 \mathrm{gm}$ \\
\hline Peptone & $5 \mathrm{gm}$ \\
\hline Sucrose & $15 \mathrm{gm}$ \\
\hline Sodium nitrate & $5 \mathrm{gm}$ \\
\hline Yeast extract & $5 \mathrm{gm}$ \\
\hline Distilled water & $1 \mathrm{~L}$ \\
\hline pH & 7.0 \\
\hline
\end{tabular}

Table .11 Representation of \% decolorization of congo red $50 \mathrm{ppm}$ dye and \% inoculum (consortium) in 10 hours

\begin{tabular}{|c|c|c|c|}
\hline S.No. & \% inoculums (\%) & $\begin{array}{c}\text { O.D. at } \\
\mathbf{4 9 5 . 6} \mathbf{~ n m}\end{array}$ & $\begin{array}{c}\text { \% decolorization } \\
(\mathbf{\%})\end{array}$ \\
\hline 1. & Positive control & 0.944 & \\
\hline 2. & 0.2 & 0.021 & 97.77 \\
\hline 3. & 0.4 & 0.018 & 98.09 \\
\hline 4. & 0.6 & 0.011 & 98.83 \\
\hline 5. & 0.8 & 0.01 & 98.94 \\
\hline 6. & 1 & 0.003 & 99.68 \\
\hline
\end{tabular}


Table.12 Representation of the growth kinetics of AMS-XI, AMS-XIII and consortium at 600 $\mathrm{nm}$

\begin{tabular}{|c|c|c|c|}
\hline Hours & & \multicolumn{3}{|c|}{ O.D. at 600 nm } \\
\hline & AMS-XIII & AMS-XI & Consortium \\
\hline $\mathbf{1}$ & 0.031 & 0.036 & 0.064 \\
\hline $\mathbf{2}$ & 0.045 & 0.061 & 0.086 \\
\hline $\mathbf{3}$ & 0.096 & 0.081 & 0.129 \\
\hline $\mathbf{4}$ & 0.160 & 0.175 & 0.260 \\
\hline $\mathbf{5}$ & 0.191 & 0.351 & 0.513 \\
\hline $\mathbf{6}$ & 0.264 & 0.482 & 0.609 \\
\hline $\mathbf{7}$ & 0.296 & 0.623 & 0.809 \\
\hline $\mathbf{8}$ & 0.350 & 0.784 & 0.965 \\
\hline $\mathbf{9}$ & 0.367 & 0.778 & 1.120 \\
\hline $\mathbf{1 0}$ & 0.383 & 0.780 & 1.175 \\
\hline
\end{tabular}

Table.13 Representation of kinetics \% decolorization of 50 ppm congo red dye by AMS-XIII and consortium with time in hours

\begin{tabular}{|c|c|c|c|c|c|}
\hline \multirow{2}{*}{ Hours } & \multicolumn{3}{|c|}{ O.D. at 495.6 nm } & \multicolumn{2}{c|}{ \% Decolorization } \\
\cline { 2 - 6 } & AMS-XIII & AMS-XI & Consortium & AMS-XIII & Consortium \\
\hline $\mathbf{1}$ & $\begin{array}{c}\text { Positive } \\
\text { control }\end{array}$ & 1.132 & 1.132 & 1.132 & - \\
\hline $\mathbf{2}$ & 1.110 & 1.179 & 1.112 & 1.9 & 1.7 \\
\hline $\mathbf{3}$ & 1.113 & 1.217 & 1.110 & 1.6 & 1.9 \\
\hline $\mathbf{4}$ & 1.087 & 1.328 & 1.106 & 3.0 & 2.2 \\
\hline $\mathbf{5}$ & 0.973 & 1.262 & 0.969 & 14.04 & 14.39 \\
\hline $\mathbf{6}$ & 0.809 & 1.251 & 0.610 & 28.53 & 46.11 \\
\hline $\mathbf{7}$ & 0.632 & 1.335 & 0.421 & 44.16 & 62.80 \\
\hline $\mathbf{8}$ & 0.353 & 1.223 & 0.143 & 68.81 & 87.36 \\
\hline $\mathbf{9}$ & 0.134 & 1.172 & 0.014 & 88.16 & 98.76 \\
\hline $\mathbf{1 0}$ & 0.061 & 1.320 & 0.012 & 94.61 & 98.93 \\
\hline $\mathbf{1 1}$ & 0.011 & 1.201 & 0.010 & 99.02 & 99.11 \\
\hline
\end{tabular}


Fig.3 After biochemical testing it was observed that the culture AMS-XI was Aneurinibacillus sp. strain and AMS-XIII was Paenibacillus sp. strain.
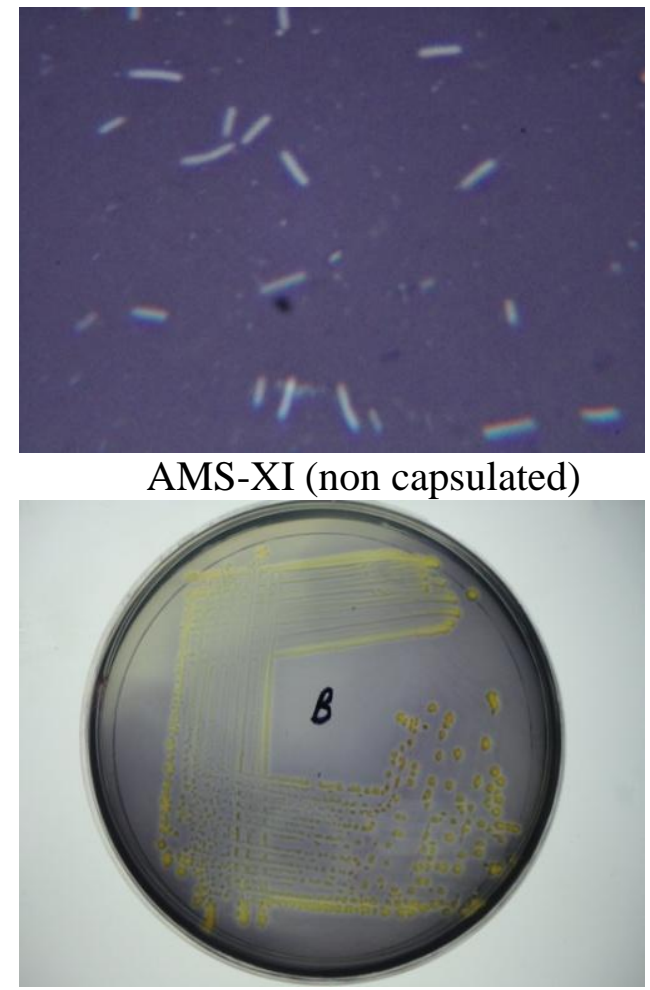

AMS-XI ( no starch hydrolysis)

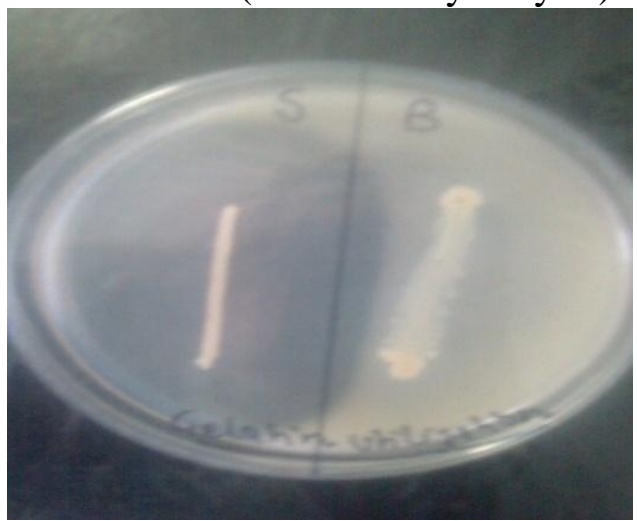

[AMS-XI(-ve), AMS-XIII(+ve)

Gelatin hydrolysis]

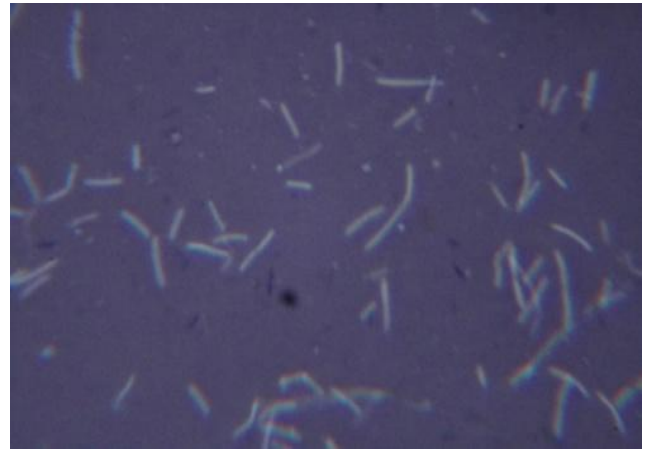

AMS-XIII (non capsulated)

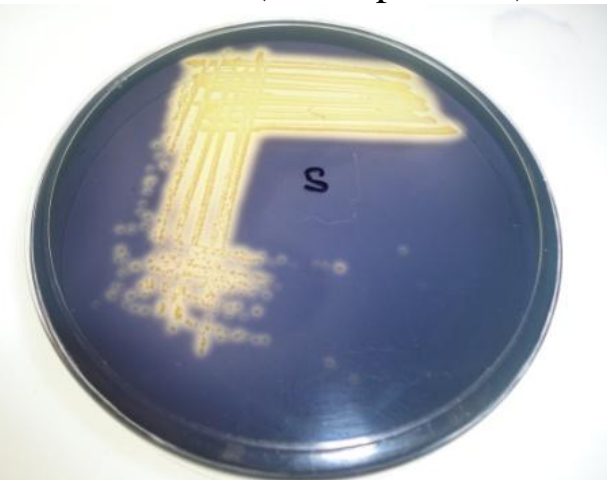

AMS-XIII (starch hydrolysis)

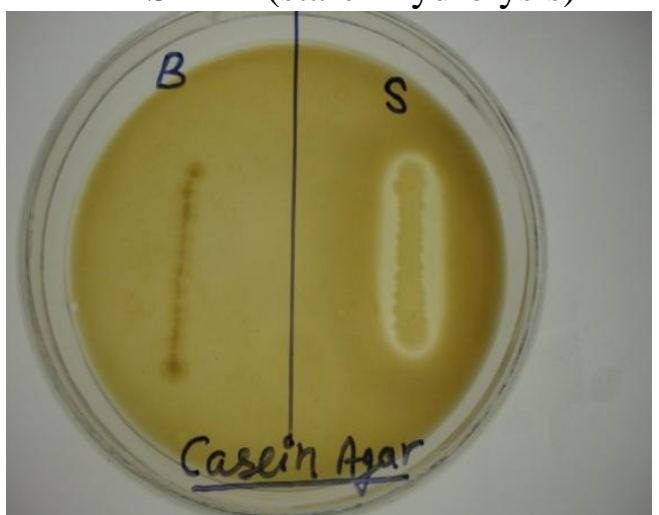

[AMS-XI(-ve), AMS-XIII(+ve) casein hydrolysis] 
Fig.4 Representation of YMB media with mixture of dyes (amido black, congo red, acid orange $\mathrm{G}$ ) each with $25 \mathrm{ppm}$ concentration (a) before decolorization (b) after decolorization of 24 hours incubation period by consortium

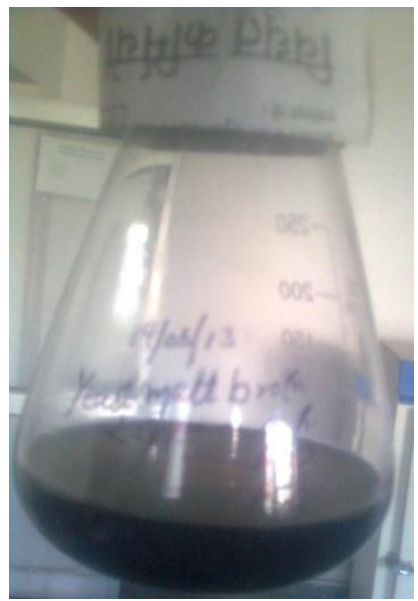

(a)

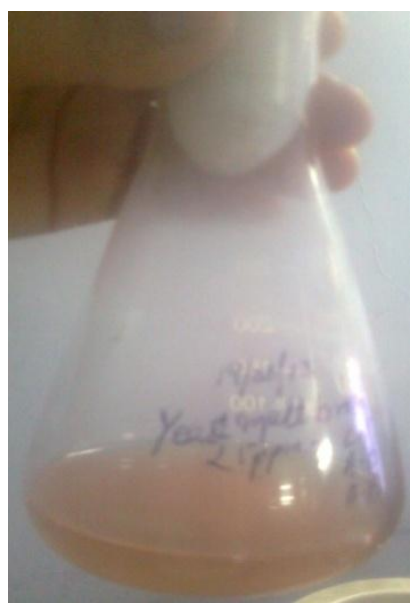

(b)

Fig.5 Representation of \% decolorization of $50 \mathrm{ppm}$ congo red dye by different carbon sources $(1.5 \%)$ by bacterial consortium in 14 hours

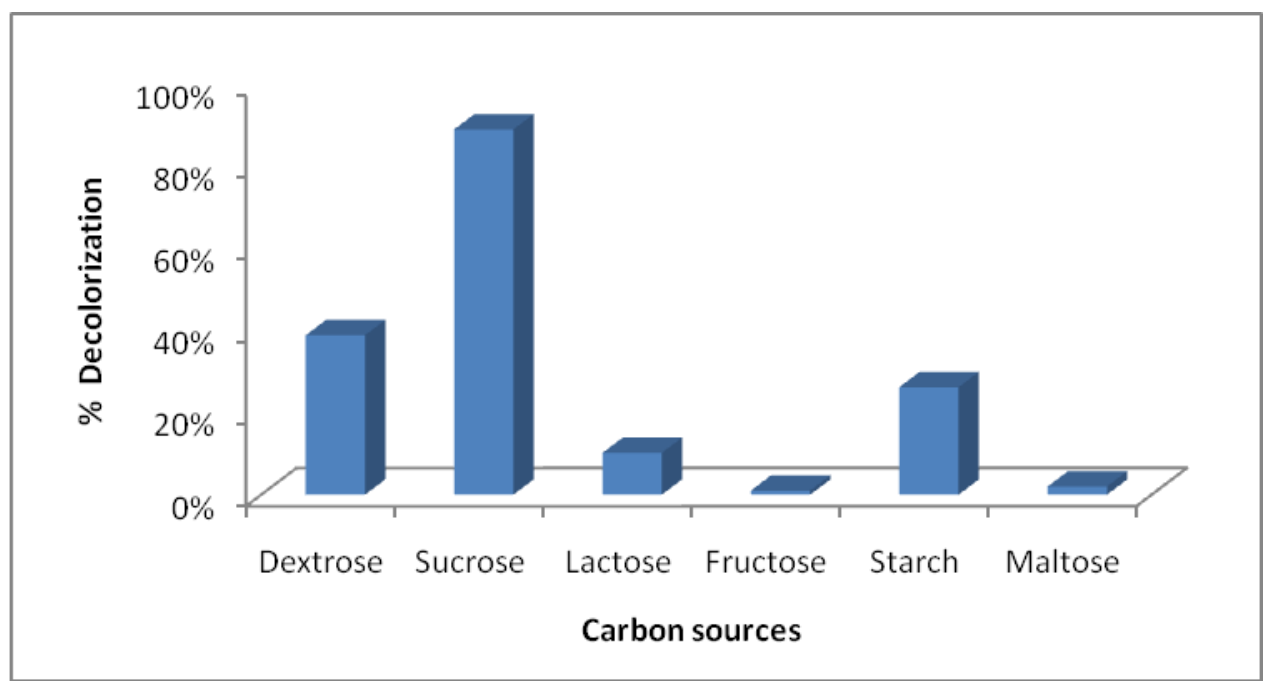


Fig.6 Representation of \% decolorization of 50ppm congo red dye by different nitrogen sources $(0.5 \%)$ by bacterial consortium in 14 hours

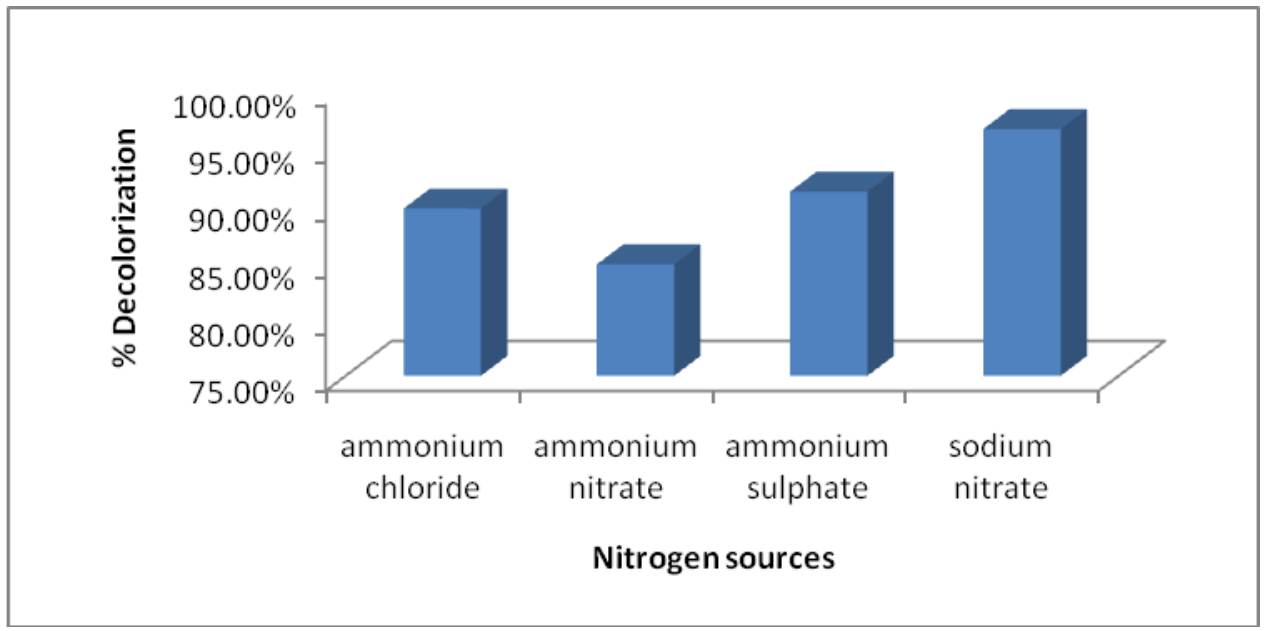

Fig.7 Representation of \% decolorization of congo red $50 \mathrm{ppm}$ dye with \% inoculums (bacterial consortium) in 10 hours

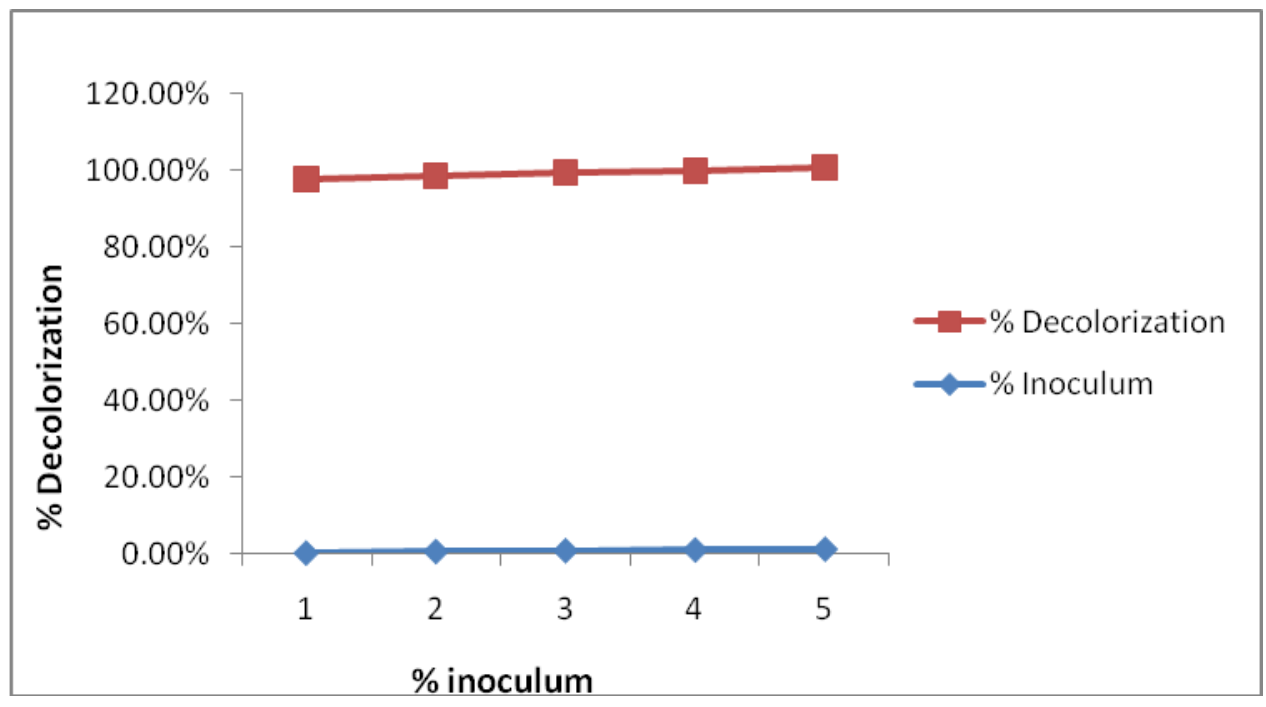


Fig.8 Representation of the growth curve of AMS-XIII, AMS-XI and consortium cultures with time (hours)

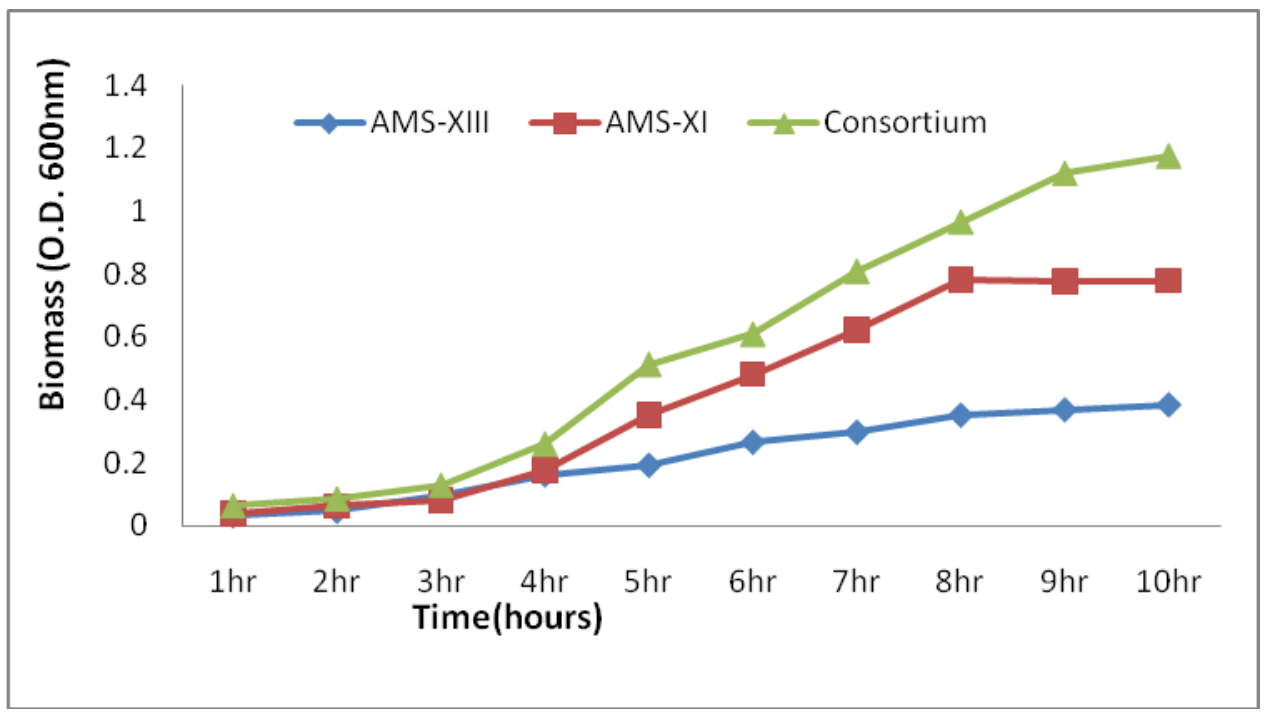

Fig.9 Representation of \% decolorization of congo red 50ppm dye by AMS-XIII and consortium cultures with time (hours)

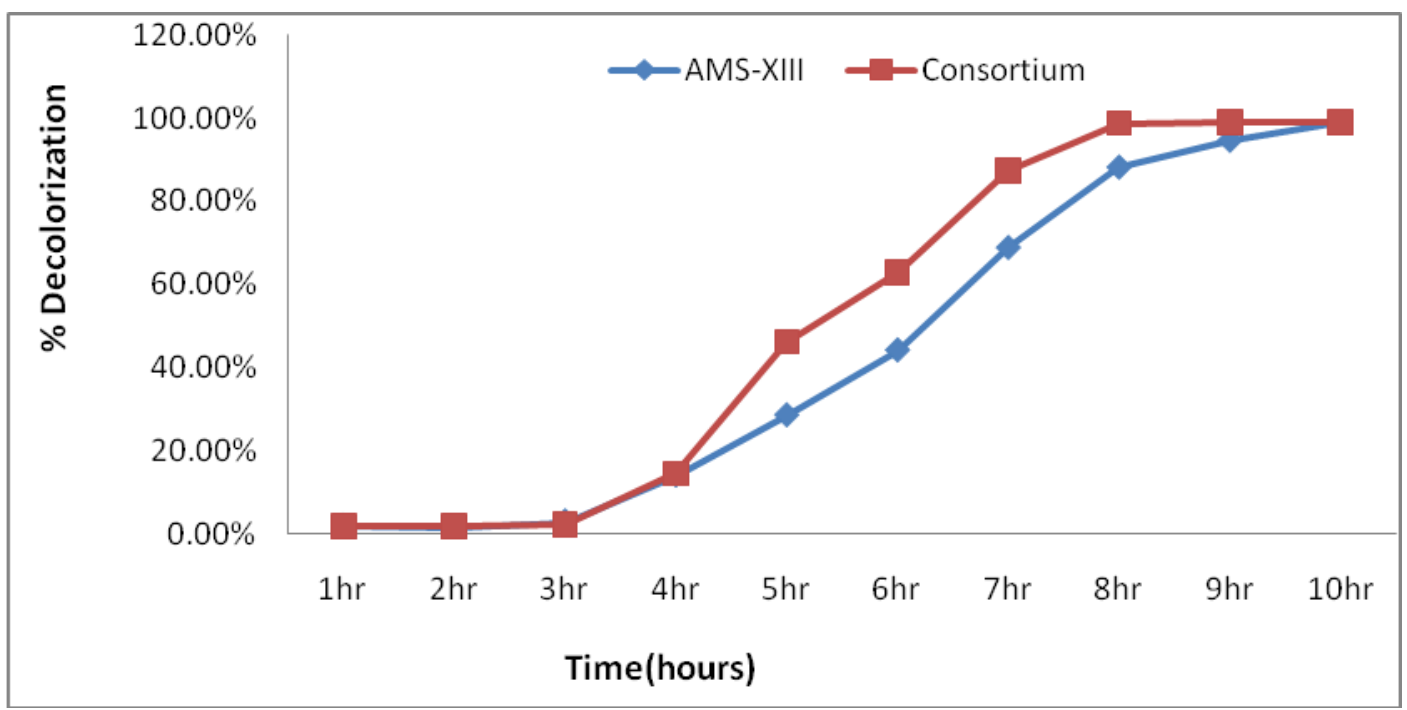


Fig.10 Representation of separation of metabolites on TLC plates (a) sample from marked vial S AMS-XIII and (b) sample from marked vial AMS-XIII

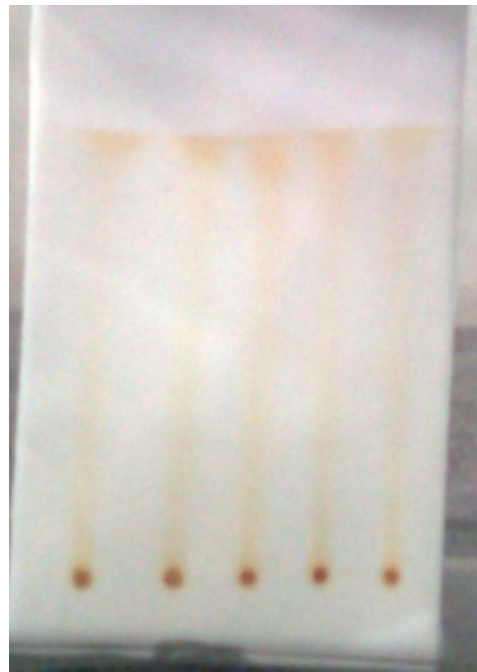

(a)

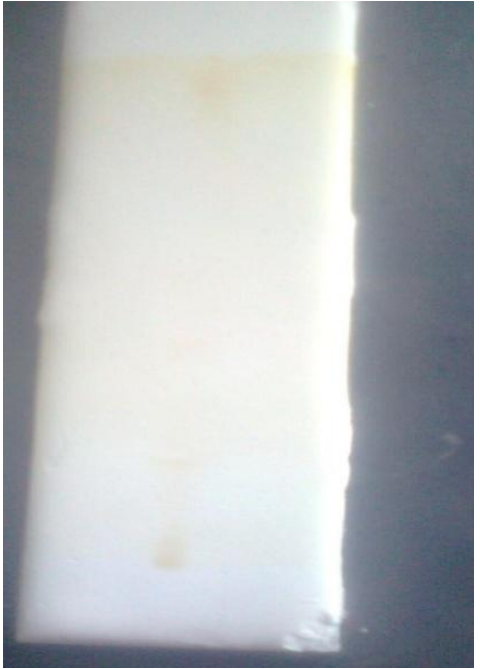

(b)

Fig.11 Proton NMR of sample vial AMS-XIII showed the presence of esters, aromatic and aliphatic compounds

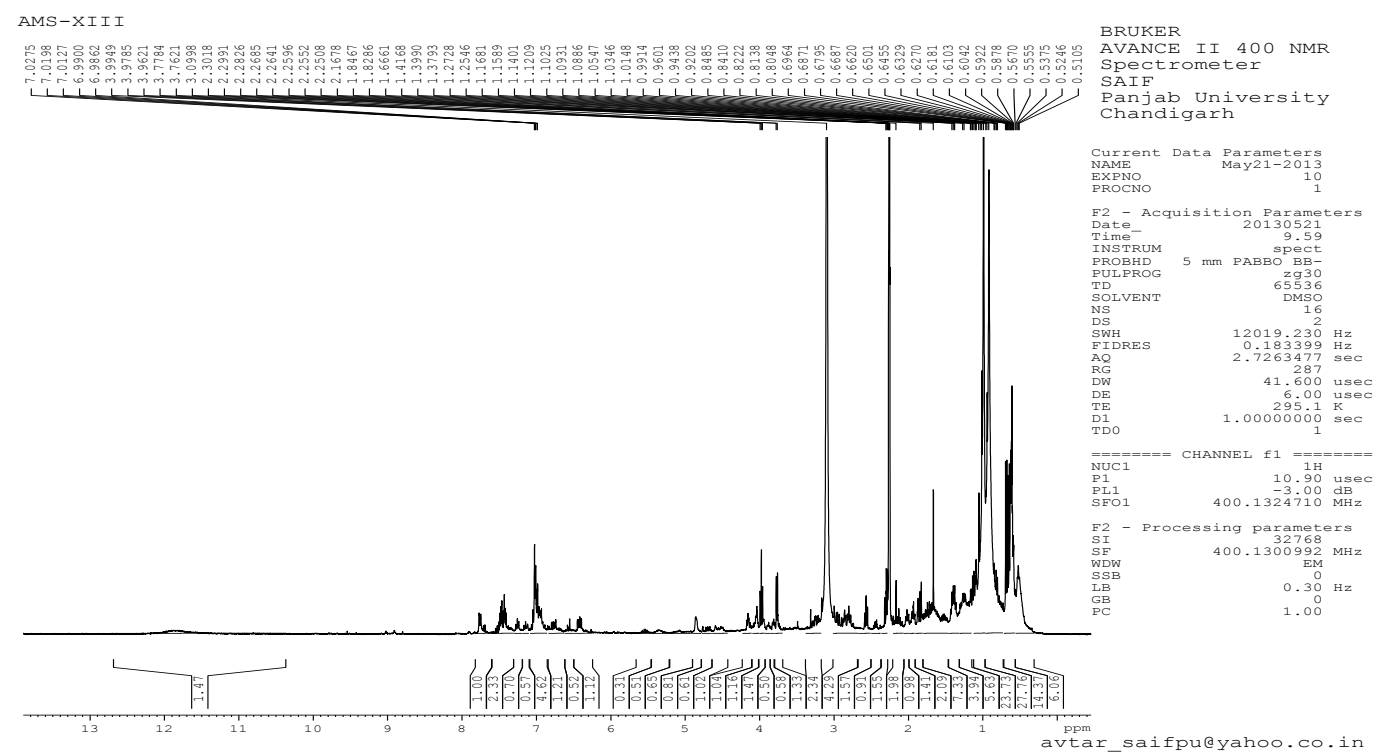


Fig.12 Representation of Proton NMR showing the presence aliphatic hydrocarbon

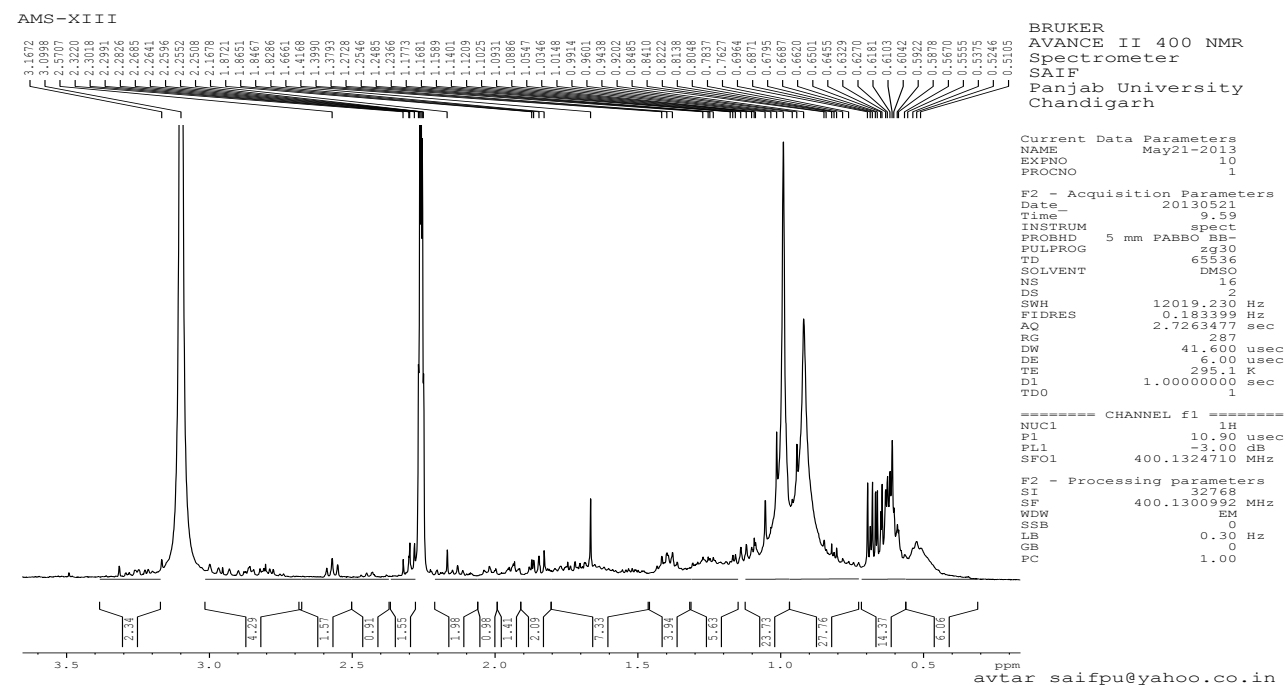

Fig.13 Representation of proton NMR showing the presence of aromatic hydrocarbon

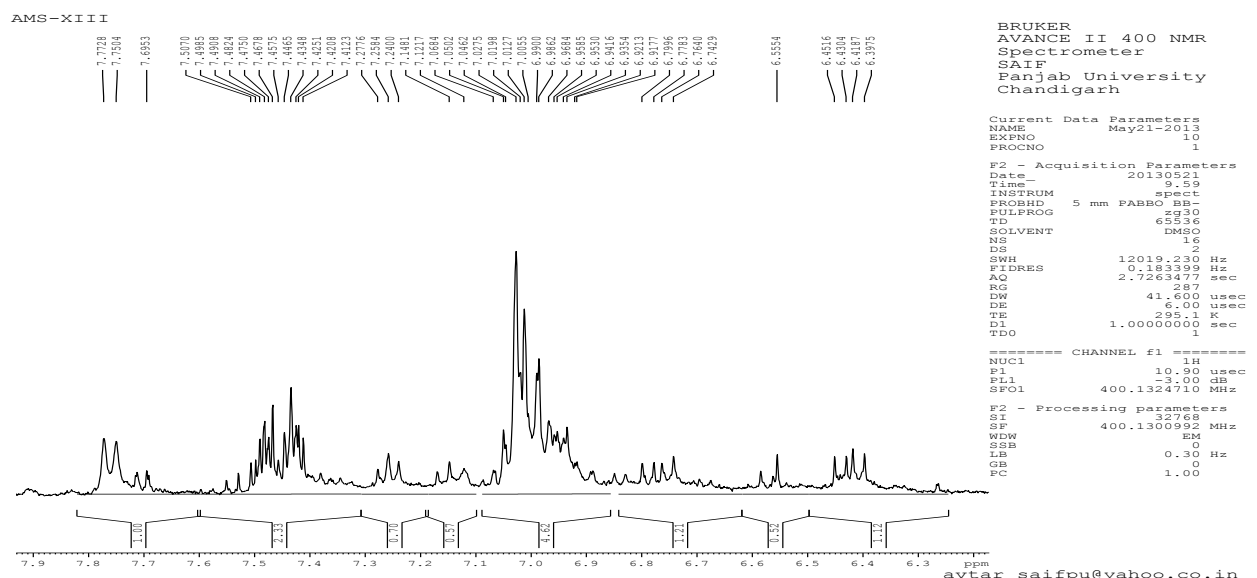

Acid Red 88 by a consortium based on four acclimatized bacterial strains belonging to Stenotrophomonas sp., Pseudomonas sp., Bacillus sp., and confirmed the biotransformation of parent dye into unrelated non- aromatic compounds. Ayed et al., 2012 observed the aliphatic hydrocarbons and some methylene after biodegradation of textile waste water by NMR spectral analysis

Fetyan et al., (2013) reported the several degradation products benzenesulfonic acid and hydroxyl- benzenesulfonic acid by NMR analysis after degradation of dye Reactive
Violet 5 by Bacillus cereus. Shah, 2014 also reported the degraded metabolites benzenesulfonic acid, hydroxybenzenesulfonic acid of RV5 dye by NMR spectral analysis.

\section{Industrial effluent treatment assay}

Industrial effluent treatment assay showed initial COD and final COD were $686.4 \mathrm{mg} / \mathrm{L}$ $160 \mathrm{mg} / \mathrm{L}$ respectively and total COD removal (\%) after biodegradation in 10 hours was $76.68 \%$. Isolated suitable consortium strains showed $98.35 \%$ decolorization of $50 \mathrm{ppm}$ 
congo red dye in YMB medium $(\mathrm{pH} 7.0)$ after 24 hours of incubation period at $37^{\circ} \mathrm{C}$ and was identified as Aneurinibacillus sp. Strain (AMS-XI) and Paenibacillus sp. Strain (AMSXIII). Media was optimized with six different carbon sources (dextrose, sucrose, fructose, maltose, starch, lactose) each with different concentrations $(0.5 \%, 1 \%, 1.5 \%, 2 \%)$ and four different nitrogen sources (ammonium chloride, ammonium sulphate, ammonium nitrate, sodium nitrate) each with different concentrations $(0.25 \%, 0.5 \%, 0.75 \%, 1 \%)$ in order to study the carbon and nitrogen source at which concentration supported fast and maximum decolorization of 50ppm congo red dye in minimum time. YMB showed maximum decolorization in 14 hours at $37^{\circ} \mathrm{C}$ under static condition. The decolorization efficiency of consortium was decreased in shaking conditions. Kinetics of \% decolorization showed the $99.11 \%$ in 14 hours by bacterial consortium and biomass concentration of consortium $0.15 \mathrm{gm} / \mathrm{ml}$ was observed after 22 hours. It was observed that when the concentration of inoculums was increased, \% decolorization was also increased in minimum time. It was also observed that culture AMS-XI was not decolorized the dye but in its presence, culture AMS-XIII showed fast decolorization and growth.TLC technique was also used to check the presence of metabolites after decolorization in the form of spots observed in UV-transilluminator. After TLC proton NMR was also done and it was detected that some esters, aliphatic and aromatic compounds were formed after decolorization. In industrial wastewater treatment showed $76.68 \%$ COD removal in 10 hours. In future it could successfully be employed in the treatment of textile effluent.

\section{References}

Abd El-Kader, Sh.F., El-Chaghaby1, G.A., Khalafalla, G.M., Refae, R.I. and Elshishtawy, H.M. 2018. A novel microbial consortium from sheep compost for decolorization and degradation of Congo red. GJESM, 5(1): 61-70.

Abedin, M.A. 2008. Decolourisation and biodegradation of crystal violet and malachite green by Fusarium solani (Martius) Saccardo. A comparative study on biosorption of dyes by the dead fungal biomass. AEJB, 1(2): 1731.

Abo-State, M.A.M., Saleh, Y.E. and Hazaa, H.A. 2017. Decolorization by congo red dye by bacterial isolates. JEHE, 5(2): 41-48.

Asses, N., Ayed, L., Hkiri, N. and Hamdi, M. 2018. Congo red decolorization and detoxification by Aspergillus niger: Removal mechanisms and dye degradation pathway. Biomed. Res. Int 9.

Ayed, L., Ksibi, I., Cheref, A., and Bakhrouf, A., 2012. Response surface methodology for optimization of the treatment of textile wastewater by a novel bacterial consortium: Enzymes and metabolites characterization. Afr. J. Biotechnol., 11(59): 12339-12355.

Bankole, P.O., Adekunle, A.A., Obidi, O.F., Chandanshive, V.V., Govindwar, S.P. 2018. Biodegradation and detoxification of Scarlet RR dye by a newly isolated filamentous fungus, Peyronellaea prosopidis. Sustain. Environ. Res., 28: 214-222.

Bouraie, M.El. and Din., W.S.El., 2016. Biodegradation of Reactive Black 5 by Aeromonas hydrophila strain isolated from dye-contaminated textile wastewater. Sustain. Environ. Res., 26: 209-216.

Chang, J.S., Chou, C., Lin, Y.C., Lin, P.J., Ho, J.Y. and $\mathrm{Hu}$, T.L. 2001. Kinetic characteristics of bacterial azo-dye decolorization by Pseudomonas 
luteola. Water Res., 35(12): 28412850.

Chen, K.C., J.Y. Wu, D.J. Liou and Hwang, S.C.J. 2003. Decolorization of the textile dyes by newly isolated bacterial strains. J. Biotechnol. 101: 5768.

Cui., D., Li., G., Zhao, M. and Han, S. 2014. Decolourization of azo dyes by a newly isolated Klebsiella sp. strain Y3 and effects of various factors on biodegradation. Biotechnol. Biotec. Eq., 28(3): 478-486.

Fetyan, A.H., Ali, M.M.S. and Break, L.M. 2013. Biodegradation of textile mono dye: Reactive violet 5 by a novel isolated bacterial strain. Life Sci., 10(6s).

Jadhav, J.P., Phugare, S.S., Dhanve, R.S. and Jadhav, S.B. 2011. Rapid biodegradation and decolorization of Direct Orange 39 (Orange TGLL) by an isolated bacterium Pseudomonas aeroginosa strain BC. Biodegradation, 21: 453-463.

Jalandoni-Buan, A.C., Decena-Soliven, A.L.A., E.P., Cao, Baarraquio, V.L. and Barraquio, W.L. 2010. Characterization and Identification of Congo red decolourizing bacteria from monocultures and consortia. Philipp. J. Sci., 139 (1):71-78.

Joshi, P.A., Jaybhaye, S. and Mhatre, K. 2015. Biodegradation of dyes using consortium of bacterial strains isolated from textile effluent. Euro. J. Exp. Bio., 5(7): 36-40.

Khehra, M.S., Saini, H.S., Chadha, B.S. and Chimni, S.S. 2004. Biotreatment of Synthetic Textile Wastewater Using Anoxic-aerobic Sequential Bioreactor.

Lalnunhlimi, S. and Krishnaswamy, V. 2016. Decolorization of azo dyes (Direct Blue 151 and Direct Red 31) by moderately alkaliphilic bacterial consortium. Braz. J. Microbiol., 47(1).

Mabrouk, M.E.M. and Yusef, H.H. 2008.
Decolourization of fast red by Bacillus subtilis HH. JASR, 4: 262-269.

Nithya, R. and Ragunathan R. 2011. Decolorization of the dye congo red by Pleurotus sajor caju silver nanoparticle. International Conference on Food and Biotechnology IPCBEE, 9.

Olukanni, O.D., Osuntoki, A.A. and Gbenle, G.O. 2009. Decolourization of azo dyes by strain of Micrococcus isolated from a refuse dump soil. Biotechnology, 8: 442-448.

Perumal, K., Malleswari, R.B., Catherin, A. and Moorthy, T.A.S. 2012. Decolourization of Congo Red dye by bacterial consortium isolated from dye contaminated soil. J. Microbiol. Biotech. Res., 2(3): 475-48.

Saranraj, P., Sumathi, V., Reetha, D. and Stella, D. 2010 Fungal decolourization of direct azo dyes and biodegradation of textile dye effluent. $J$. of Ecobiotechnol. 2/7: 12-16.

Sarkar, S., Banerjee, A., Halder, U., Biswas, R. and Bandopadhyay, R. 2017. Degradation of synthetic azo dyes of textile industry: A sustainable approach using microbial enzymes. Water Conserv. Sci. Eng., 2:121-131.

Sawhney, R. and Kumar, A. 2011. Congo Red (Azo dye) decolourization by local isolate VT-II inhabiting dye effluent exposed soil. Int. J. Environ. Sci., 1(6): 1261-1267.

Shah, M.P. 2014. Microbial degradation of azo dye by Pseudomonas spp 2413 isolated from activated sludge of common effluent treatment plant. IJEBB, 2(3): 133-138.

Singh, P.K. and Singh, R.L. 2017. Bioremoval of Azo Dyes: A Review. IJASBT, 5(2): 108-126.

Sriram, N. and Reetha, D. 2015. Isolation and characterization of dye degradaing bacteria from textile dye effluents. 
Cent. Eur. J. Exp. Biol., 4(2):5-10.

Talarposhti, A.M., Donnelly, T. and Anderson, G. 2001. Colour removal from a stimulated dye wastewater using a two phase anaerobic packed bed reactor. Water Res., 35:425-432.

Tripathi, A. and Srivastava, S.K., 2011. Biodecolorization of Azo dye, Acid Orange 10, using different bacterial strains. $2^{\text {nd }}$ International Conference on Environmental Science and Technology IPCBEE, 6.

Vimala, G., Jeyakumar, P., Devi., A., Singh, C.A. and Iyer, P. 2015. Azo dye degrading bacteria from textile effluent. IJCMAS, 4(7): 199-210.

Viral, S. and Patel, K. 2012. Degradation of Azo dye Acid blue 158 by soil microbes. Research Journal of Biotechnology, 7(2).

Yang, P., Shi, W., Wang, H. and Liu, H. 2016. Screening of freshwater fungi for decolorizing multiple synthetic dyes. Braz. J. Microbiol. 47: 828-834.

Sawhney, R. and Kumar, A. 2011. Congo Red (Azo dye) decolourization by local isolate VT-II inhabiting dye effluent exposed soil. Int. J. Environ. Sci., 1(6): 1261-1267.
Shah, M.P. 2014. Microbial degradation of azo dye by Pseudomonas spp 2413 isolated from activated sludge of common effluent treatment plant. IJEBB, 2(3):133-138.

Talarposhti, A.M., Donnelly, T. and Anderson, G. 2001. Colour removal from a stimulated dye wastewater using a two phase anaerobic packed bed reactor. Water Res., 35:425-432.

Tripathi, A. and Srivastava, S.K., 2011. Biodecolorization of Azo dye, Acid Orange 10, using different bacterial strains. $2^{\text {nd }}$ International Conference on Environmental Science and Technology IPCBEE, 6.

Vimala, G., Jeyakumar, P., Devi., A., Singh, C.A. and Iyer, P. 2015. Azo dye degrading bacteria from textile effluent. IJCMAS, 4(7): 199-210.

Viral S. and Patel Kunjal., 2012. Degradation of Azo dye Acid blue 158 by soil microbes. Research Journal of Biotechnology, 7(2).

Yang, P., Shi, W., Wang, H. and Liu, H. 2016. Screening of freshwater fungi for decolorizing multiple synthetic dyes. Braz. J. Microbiol. 47: 828-834.

\section{How to cite this article:}

Sunanda Kumari and Preeti Rajoriya. 2019. Textile Industrial Effluent Treatment by Azo Dye Decolorizing Bacterial Consortium. Int.J.Curr.Microbiol.App.Sci. 8(11): 884-907. doi: https://doi.org/10.20546/ijcmas.2019.811.105 